\title{
BINARY PATRIARCHY IN NIKAH SIRI: An Ecofeminism Perspective
}

\author{
Aisyah Arsyad \\ Theology and Philosophy Faculty \\ Universitas Islam Negeri Alauddin Makassar \\ Email: aisyah.arsyad@uin-alauddin.ac.id
}

Abstract : Nikah Siri (unregistered, or 'secret' marriage) has increased in Indonesia since the passing of marriage law No. $1 / 1974$, one article of which required the registration of all marriages. Meanwhile, under Islamic law (fikib munakahat), registration was not one of the pillars of marriage. The 1974 state law provides for penalties for persons involved in unregistered marriages such as nikah siri: on the other hand, under Islamic law nikah siri was considered as marriage, as the terms and the pillars of marriage were fulfilled, even without registration. Religious and state law are clearly at odds as far as marriage registration is concerned.

Gradually, Nikah Siri has led to various forms of social problems such as nikah siri online, falsification of documents, and even human trafficking. The main problem which is one focus of this research is the negative impact of nikah siri on women and children. Not having an official marriage registration document creates difficulties for women and children which affects their future life opportunities, as with children not being accepted for schooling, as one example. One significant legal ruling discussed has implications for this social deprivation of women and children but not to the extent expected to date.

By using the concepts of dualism from ecofeminism theory (perspective) to analyse the role of patriarchy in creating and perpetuating gender inequality in the case of nikah siri, the writer argues that Islamic marriage law - as it has developed in Indonesia - is still dominated by patriarchal values and, as such, impacts negatively on women and 
children. The stereotype of istri siri is proven in that the hierarchical dualism that underlies patriarchal structures and thinking, is placing women in a subordinate position. Patriarchal interpretations of Islamic law have put many women in a position where they regard nikah siri as the best option for themselves, although such marriages in fact place them in a precarious position legally and socially, and lead to an imbalance of power both between themselves and the men they marry, and any other legal wives of that man.

Keywords : Nikah Siri - Social Problem - Patriarchy -

$$
\text { Dualism }
$$

\section{Introduction}

Nikah Siri, or unregistered, or 'secret' marriage, has emerged in the form of a recent phenomenon that has grabbed the attention of the media and society. This new type of marriage phenomenon, known as nikah siri online, has increased widely. This practice, whereby a bride and groom are married without, as the name suggests, ever meeting faceto-face and importantly, without the presence of the guardian (wali) of the bride, has been widely condemned by many religious experts and state officials who have characterised it as hidden prostitution. But in fact, nikah siri online can be regarded as a logical consequence of a legal system that demands that marriages are registered by the state, but IT does nothing to enforce this requirement and, thus, condones unregistered marriages in practice.

The issue of nikah siri is an increasingly controversial one, and thus this research, which examines the practice both in terms of state law and Islamic law, is a timely one. While 
state law requires registration of marriage, and some ulama strongly oppose marriages that take place outside such legal guidelines, other ulama argue that as long as the pillars of marriage according to Islamic law are met, such marriages are valid, as registration of the marriage is not included as a precondition for the validity of a marriage. This was affirmed by the Majlis Ulama Indonesia (MUI; Indonesian Council of Ulama) fatwa of 2006.

The phenomenon of Nikah Siri Online was discussed in early 2015, noting that marriage law still gives space to marriages conducted without official registration by the state. That was until Nikah Siri Online increased. Ministry of Religious Affairs (Kemenag) information is that there are about 45 sites that offer services for Nikah Siri Online spread across Java (Jakarta, Semarang, Yogyakarta and Surabaya). But even more than that number (45 sites) was listed by the Director General of Islamic Guidance MORA RI. Nikah Siri Online was regarded as an offense or violation and not justified according to Moslem scholars (religion?) and state law, and even, in some quarters, was regarded as a vote for prostitution. Many responses and comments appeared not only from women but also from scholars and government officials, and various opinions circled about this rampant model of marriage, as it CAUGHT the public EYE.

The debate surrounding the status of Nikah Siri itself is still problematic. The advice from moslem scholars (MUI) not to practise Nikeab Siri and that people should not register their marriages to the competent authority (KUA) is not 
completely followed.This is due to the opinion held by moslem scholars (MUI) which still considers that Nikah Siri is legal, as long as the main pillars of marriage were fulfilled. Similarly, although the law states that a marriage that is not registered is in violation of the law, it is difficult to take legal action because of the controversy between religious and state law.

The polemics about Nikah Siri were prolonged with its evolution into Nikah Siri Online, because authorised religions consider it legitimate as it met their terms though there was no registration. The state (in this case the marriage law) has determined that marriage that is not registered with the competent institution is regarded as being in violation of the law. Practically, the more real negative impact is that this has led to the discrimination against women and children. Another issue that also contributed to strengthening the preservation of Nikah Siri is the dualism of family law as adopted by the Republic of Indonesia (the national/state law and religious law), which applies to the Muslim community in Indonesia.

The principle of monogamy in marriage is considered by some to be restrictive and not in accordance with Islamic law which allows polygamy. Meanwhile, adultery or having sex outside of marriage have been equally clearly prohibited by religion. Consequently, the fulfilment of sexual desire is considered problematic/complicated, and is strictly limited, as compliance is virtually impossible without violation either against the law or against the normative law.??? Coupled with 
this is the culture of a society so burden in implementing marriage. "Marriage social price that must be paid" thus making the fulfilment of human's desire increasingly shackled by a complex social system and rambling as for instance, with the traditions in marriage money shopping, parties, administrative requirements and others. Yet the fulfilment of sexual desires - like human needs for food and drink - means that desire needs to be fulfilled, otherwise it will cause effects, both psychologically and socially, which are very likely to violate social norms, law and religion.

In this perspective, with people increasingly highly socially mobile, space almost without limit (???) and subject to exploitative economic demands, crime and sexual morality, such as rape, harassment and adultery have become general phenomena, such that the Nikah Siri has become a kind of temporal and uncomplicated solution

Nikah Siri has been known for a long time in Indonesian society, so the history of the beginning of its existence and the origin of the term cannot be identified, with certainty. The term Nikah Siri is actually unknown in classical fiqh (explanation required) and is not a term that can be found in religious literature. The history of the emergence of this term is probably in the time of Caliph Umar bin Khattab. When he was told that there was a marriage that was not attended by sufficient witnesses, Umar said: "This is a Nikah Siri and I did not allow it, and if I yet come for sure I will pelted". The marriage was considered as Nikah Siri because of the problem of inadequate witness. It needs to be underlined from the 
quote from Umar that when he is talking about the punishment he would inflict, it is aligned with the law on adultery. From this we can actually understand that Nikah Siri will be very vulnerable fall to adultery.

According to Machasin, Nikah Siri is an old phenomenon. In fact, it was booming in Yogyakarta in 19751985 and was the one thing for students who were dating, to justify their sexual intercourse. This issue was raised in Indonesia in 1973 after the establishment of the STATE regulation about the registration of marriages. After 1974, marriage without registration was not allowed. Marriages that took place before that period, could be registered with the Religious Court for the confirmation of marriages, which is commonly called Isbat Nikah (the Confirmation of Marriage).

\section{The Case of Machica Mukhtar}

In 2010; Aisyah Mukhtar (Machicha) was fighting for the rightS of her son (Muhammad Iqbal) who was born as a result of her nikah siri with Moerdiono (one of the former ministers in the Soeharto government)VICE-PRESIDENT. The couple married in an Islamic ceremony in 1993 and in 1996, a child was born TO this unregistered marriage. In 1998, Moerdiono divorced Machica and had no further contact with the child, refusing to acknowledge that the child was his. EVEN uUntil her child was a teenager, he never received acknowledgement from his father (Moerdiono). Hence, Machica eventually took the case to the Constitutional Court, asking that the court review the section of the marriage 
law that mandated the registration of marriages, arguing that a marriage that was valid according to Islamic law could not be invalidated by man-made laws. The first thing she needed to do was to validate the marriage in the Religious Court, Tigaraksa Tangerang. So, she obtained a Nikah Siri determination from the Central Jakarta Religious Court on June 18, 2008. Then, in July 2008, Moerdiono's family released a press release saying that they did not recognize Muhammad Iqbal as a son of Moerdiono. At that time, the fight between Machica with Moerdiono and his extended family (even after Moerdiono died in 2011) began. Machica, on several occasions, stated that she would continue to fight for her son to get what was rightfully earned by a child, especially his father's approval.

Then in 2010 Machica began a judicial review (PK) on the validation of her son by issuing a judicial (judicial) challenge on two grounds. The first was the validity of article 2, paragraph (2) of the recording of the wedding. Machica explained that constitutionally anyone has the right to perform marriages as long as it was in accordance with the teachings of religion and belief in each other. In that regard, the applicant to perform marriages in accordance with the norms of Islam and have qualified and pillars as stated in the teachings of Islam, though not recorded officially at KUA. In this context, the applicant argued that the validity of the marriage may not be able meredusir by man-made legal norms, so that a valid marriage becomes invalid. Any legal consequences become very large. Not only marital status is 
not clear, but also related to the status of children born into uncertainty. The second was Article 43 paragraph (1) of Law No. 1 of 1974 on the status of children to the Constitutional Court (then held by Mahfud MD).

She also asked that the section of the marriage law dealing with the status of a child born out of wedlock be amended, because it only acknowledged a legal relationship between the child, mother and mother's family. Before the verdict from the Constitutional Court, Moerdiono died on October 7, 2011. But it did not deter Machica from continuing to fight for her rights. Then on February 13, 2012, the Court announced its decision, namely, first, to reject the judicial review article 2, paragraph (2) of Law No. 1 of 1974, and the second, received a judicial review of Article 43 paragraph (1) of Law No. 1 of 1974 and states: "..... a child born out of wedlock have a civil relationship with her mother and her mother's family", contrary to the Constitution of the Republic of Indonesia Year 1945 meant eliminating all civil relations with a man who can be proved by science and technology and / or other evidence according to the law turned out to have a blood relationship as a father, so that the verse should read: "children born out of wedlock have links civil with her mother and her mother's family as well as with the male as the father, which can be proved by science and technological and / or other evidence according to the law have blood relations, including civil relations with his father's family. "The Constitutional Court's decision later controversy in the community because they have far-reaching consequences that 
although on the one hand successfully completed the issue of protection of children who abused his trust status, but also could lead to new problems. In view of Oyo Sunaryo Mukhlas that "do not reasons to protect and acknowledge the sacred child who was born just opened" the door "of unlimited freedom, including her bejadorang deeds. Instead then bring up new issues. As if separated from the "tiger's nest" then go to "crocodile nest". With "transforms" Article 43 paragraph (1) of Law No. 1 of 1974, the religious fervour attached to article 2, paragraph (1) and is touted as chapter Islami, as if "denied". Though the existence of the article is actually attached and a "follow-up" on article 2, paragraph (1) of Law No. 1 of 1974. So far, the chapter has been deemed appropriate to the culture of the nation's religious education that puts marriage as the ideal for attributing the child to the mother his father, so that the position and recognition of children not only "biological child, but also a spiritual son". Further, he said that if the reasons and the establishment of the Constitutional Court's decision was to protect children (bifdz, al-nafs) in order to obtain legal certainty regarding the relationship civil, for the actors are already excessive, and produce a child in the womb, which is the argument mainstay of Constitutional Court judges, namely in order to protect the child, there was space for the protection of children conceived her, namely: through article 53, paragraph (1) KHI, which allow mating during pregnancy: "A woman is pregnant out of wedlock can be mated with the man who impregnated her". Birth of the Constitutional Court's decision is the 
government's efforts in providing protection and minimize the adverse impacts that will occur in children both before and after birth, developmental, educational, psychological, inheritance and all matters related to his life, in which the role of parents is irreplaceable by anyone.

Initially this decision not only satisfied Machica Mukhtar but also the many women who had to fight the same case for their children. Given the decision of the Court on 24 April 2013 Machica sued Moerdiono in the South Jakarta Religious Court (PA South Jakarta) requesting recognition of her marriage, and Iqbal being entitled to make a living. But unfortunately, the court refused to review the section related to the registration of marriage, but did argue that the marriage law should be amended to acknowledge civil relations between a child born out of wedlock with the father and his family as well as the mother, where this blood relationship could be established by available technological means.

This case has shown how patriarchalism dominates in marriage law, due to the negative consequences nikah siri can have for both wives and children. But nikah siri still exists till to the present.

\section{The Patriarchy Tendency in Indonesian Fiqih}

Patriarchy still dominates the interpretation of the text (nass) in term of only masculine interpretation in many cases. What is needed is a feminine reading, particularly for women's problems, such as with the relation between wife and husband in family life. 
Generally, patriarchy can be defined as a system characterized by the male (father). In this system, the man has the power to decide. This system is considered reasonable because it parallels the division of labor based on gender.

In Islamic Indonesian discourse, patriarchy became increasingly popular, when it began to be associated with Islamic religious discourse which tends to be dominated by men. Rif at Hassan in his writings al-Mar'a wa al-'Amal al-Siyasi, $\mathrm{R} u$ 'yatun Islamiyatun, said that patriarchy was a Roman concept, by which the male was head of household legal matters, expenditure and the arrangement of children's marriages. Syafiq Hasyim use the term patriarchy in terms of jurisprudence. According to him, the term 'patriarchal fikih' may sound unfamiliar as it is not found in the classical Islamic literature. 'Patriarchy', meaning the rule of the 'father', has negative connotations for many, as it suggests a system of rule by men. He used the patriarchy concept in his own study to analyse fikih, which is male discourse. But to challenge fikib is to challenge a great tradition upheld by Muslims over the centuries. Fikih in his view is rarely questioned as other branches of theology are, for instance. Therefore it has evolved more slowly.

Regarding this, Hussein Muhammad added that compared to other Islamic studies, such as kalam or theological science and ethical-moral / character studies, jurisprudence or fikih dominates every conversational discourse related to problems of human activity. Meanwhile, fikih, was still struggling with the products of the past and 
with all the problems of its own logic. Jurisprudence, at the end, is no longer seen as a real individual fatwa that should be subject to critical analysis or change. It became identical to religious laws not to be touched for contextual reasons. Jurisprudence is final and has become conservative in its discourse and doctrine. But essentially the realm of jurisprudence is one of sociological change, so it should be contextually-based. It is a very important methodological construction which operates in order to address issues in the contemporary era that were not found in classical fikih.

The most obvious characteristics in the framework of patriarchy developed by Warren are as follows: 1) patterns of thinking that are based on hierarchical values, that is the mindset that refers to relationships as "top-down", that provide value, status, prestige and more, with everything being "on top" of everything "under" it; 2) the duality of values, such as different pairs which was seen as the opposition (and not complementary) and exclusive (not inclusive), and that puts a high value or status to what has historically been identified as "body", "feeling" and " women "; 3) the logic of domination, ie the structure of the arguments that led to the justification of subordination (1996:20). The concept of a hierarchical patriarchal pattern of thinking, dualistic and oppressive of women and nature of the damage. According to Warren, because women have been naturalized and nature has defeminises, is not easy to know when to end the oppression of women and the oppression of nature begins, and vice versa. Karen J. Warren emphasized that the 
dualism threatening to destroy society are social constructions. In a capitalist, patriarchal society, women and nature, men and culture, have certain meanings but these meanings are far from necessary -unfounded?.

Syafiq Hasyim has suggested that there are several reasons why fikih has a patriarchal tendency. Firsty, fikih is a discipline of Islamic knowledge derived (istinbat) from the alQur'an and Sunna in which the Arabic language of both Islamic primary sources is derived from the patriarchal lexicography of this language. (ex. Q.s.4:34) The majority of jurists interpreted and used this verse as justification that women cannot lead the prayer for men. Secondly, the founders of fiqh are mostly male. It is evident that male subjectivity has an influential role in the process of creating fiqh narratives. If we go back to the first generation of Islam, Aisyah was the teacher of many of the prophet's companions, but her capabilities as a female ulama are not expounded on as prominently as other male companions of the prophet. Thirdly, the patriarchal predisposition of figh can be seen in the model of transmission and dissemination of this discipline, both of which are controlled by male ulama. In Indonesia, pesantrens, Islamic learning education centers and Islamic forums, which serve as venues for the formulation and spread of Islamic discourse remain the domain of male ulama. Leaders, teachers and preachers are mostly males. In the co-eduactional pesantrens or Islamic study groups, male teachers can lecture both male and female students, but the same cannot be said for female teachers. 


\section{The Oppressive in Nikah Siri: Ecofeminism Theory}

Patriarchy is a representation of masculine identity that has the political power and will. This power should not necessarily be operated by men on women. The main thing is to build a power system that can be used by both men and women. At present, power is synonymous with patriarchy.

The State as a political and legal institution, is often seen as a natural system, given and happening by itself. The State is considered apart from the interests and does not represent a particular gender, male or female. The state is genderneutral. But in fact, the state as a system of society that could not be separated from its cultural and local social system, which had existed, even before the establishment of the state itself. In this context, the argument of feminists found that the system is evolving in society as a patriarchal system. The state translates the patriarchal power into the system and ideology. Consequently, the law has become a tool of legitimacy and thus created an invisible male social dominance. In other words, state policy which appears to be aimed at everyone, men and women, actually only represent the interests of the former, resulting in imbalances in various aspects of life. Therefore, the feminists became aware of the necessity for an analysis of the relationship between women and the state to see gender inequality from the inside, whereas, in fact the state was strongly influenced by the system in the society or in other words local wisdom.

In addition, the confusion and problems related to nikeah Siri marriage still exist, and unwittingly became another 
pattern of gender dominance. The State also could not demonstrate its power by sanctioning those who violate the law, when dealing with religious law. The accusation that the state is a party to preserve the culture of patriarchy should be understood in the context of the few policy decisions that benefit women. Draft legislation to prosecute the participants in unregistered marriages, even though it received a lot of support from several parties, has actually become a double burden for women. They and their children are victims of that marriage under the marriage law No. 11974 Article 43 and reinforced by KHI Article 7. Therefore, the problem is not only how many women participate in political practices, but most importantly whether the policies made are gender responsive or not.

The patriarchal system in Nikah Siri can be explored from an ecofeminism perspective. Ecofeminism is a movement that wants to restore the importance of human consciousness in reviving feminine qualities in society. It is not anti-family, and supports the role of motherhood, but still considers that the patriarchal system is damaging the system. Ecofeminism relates to women in the various dimensions/aspects of their lives. Theoretically, the construction of violence and exploitation of women was paralleled by the relentless exploitation of the earth by the capitalist economic system that still largely exercises control through the patriarchal system. The interesting thing, somewhat different from others' ideas is that the issues of 
spirituality and the environment are important topics, when talking about women.

Karren J. Warren, as an ecofeminist, proposed the most obvious characteristics of patriarchy are as follows: 1) patterns of thinking that are based on the values of the hierarchical, with a mindset that refers to relationships in "top-down" terms and that determines value, status, or prestige as higher in all things - "on top" of everything "below"; 2) The duality of values, such as different pairs of values which are seen as being in opposition (and not complementary) and exclusive (not inclusive), and that put a value or a high status on what is historically identified as "body", "feeling" and " women ";

3) the logic of domination, the structure of the argument that led to the justification of subordination. The concept of hierarchical thinking, dualistic and logic of domination to analyse the patriarchy problem are the main framework of the oppressive actions that undermine women and nature. According to Warren's opinion, because women have been naturalized and nature has been created as feminine, it is not easy to understand when the oppression of women ended, and the oppression of nature begins.

\section{Hierarchical Patriarchi}

Traditionally, the division of working men and women was based on an hierarchy. An interpretation of the hierarchy means one is higher, such as men who work in the public sector are higher than women working in the domestic sector. Ontologically, arguments about "higher" are usually based on 
the interpretation of QS. Al-Nisa (4): 34. So, there is some sort of validity theologically of the superiority of men over women. The interpretations of these verses is personified in man as Prophet, scholar, priest and others, while there is no similar authority bestowed on woman as such .

Hierarchy and superiority over women's arguments, after approval by the theological experts also appear strongly in the sciences, as for instance, in psychology and sociobiology. In socio-biology, the argument is often put forward that explains social behaviour via genetic behaviour. For example, the emphasis on the aspects of physiological and anatomical differences between men and women or the male brain structure being different from women, because the male brain size is larger. The implication is that the male stereotype is defined by intelligence, reasoning, intellectual perfection, clarity of mind, maturity in planning and more accurate in assessment. The stereotype of women in psychology, for example, is characterised as passive, masochistic, emotional, obedient and affectionate. This is the fundamental basis justifying the traditional role of women as being in the domestic sector, which curiously is regarded as being in the nature of women. Within this framework, women working in the public sector, for whatever reason, is not considered natural. If they force themselves into the "man's world", then they had to shape themselves to accord with the masculine pattern. Another term often used is "masculinization of women" achieved by women becoming more active, free, objective and rational. 
The views of psychology and socio-biology obviously give scientific support to the theological views - from the viewpoint of the feminist - that are biased towards the interests of men and the contention that men are higher than woman is justified. There is no equality between the roles of men and women: there is only the hierarchy. With the state of women unequal with men, women clearly do not have their freedom in the presence of men. In the hierarchical order, violence becomes almost certainly inevitable. In a hierarchical society the superior group is in a position to act violently towards or oppress the group that is regarded as inferior.

Thus, the weak position of women in cases of unregistered marriage is a consequence of patriarchal values being preserved through the process of socialization and reproduction in various forms both by society and the state. Women are stereotyped as a 'istri simpanan' and with terms such as 'istri sab' or 'istri siri' embedded in the society, there is continuing support for a hierarchy in the family structure.

\section{The Dualism of value}

Psychological differences between men and women were based in both physiological and biological differences.. Such ideology was reinforced by opinions of philosophers such as Immanuel Kant and Bruno Bettelheim who affirmed that as women were weaker than men, physically and psychologically, such that it was very natural that women are dominated by men. Eventually Aristotle said that "the woman is the man who was not complete". 
According to ecofeminism theory gender ideology is 'binary'. The male is described as a perfect man, rational, active, explorative and aggressive while the female is described in terms of human weakness, emotional, passive, submissive and dependent. Consequently, women were only entrusted with tasks in the domestic area that does not necessarily require reasoning and attitudes. In the classic philosophy of Greece, nature was conceptualized as opposite cosmic twins, for example: day and night, good and bad, balanced-changing, limited-indefinitely, wet-dry, singledouble, bright-dark, sense-feelings, body and soul, men and women and so on. Thus, there are two entities which were always opposed: existentially asymmetrical and unbalanced. In this case, the first group was always connoted positively and linked with the male, while the second group had a negative connotation that was always associated with women.

The binary nature of patriarchies began with gender relations, and then continued to age, economic classification, the relation of social class, race, relations between the state, government-people relations and other relations in various forms of life. Clearly, it can be said, patriarchal gender ideology has created unequal relations based on the category of strong-weak, the strong over the weak, with its implications such as in violence and discrimination against women.

According to Nunuk P. Murniati, religion is most powerful in its ideology of gender that has the oppressed society and women would not dare to discuss it. She continued that revealing the various interpretations of 
religious teachings will lead to understanding the real issue, because the binary formula heavily influenced patriarchal interpretations of religious teachings.

Legal dualism and nikah siri is a formula for the patriarchy significantly harming women and children. The only reason that unregistered marriages still exist in the community is based on a theological justification. The debate of structurally and intellectually factor further strengthen patriarchal charge in it. The long history of legislation on marriage reinforces how great has been the influence of the dominant patriarchal values in a relationship.

\section{Logic of Domination}

The logic of domination is highest form of oppression of women, because the women themselves have legitimized the oppression to them. It can be seen, for example, in some of the reasons of participants in nikah siri. Although they know of its negative impacts, they still accept this marriage style as a solution to their needs.

According to the ecofeminism theory that oppression against women and children occurs stems from a culture of control over nature that is projected on to the control of men over women. These unequal relations in the process of human life produce various forms of domination or control in the positioning of the strong over the weak. This situation has been proven in humanity and the environment, both the social environment and the natural environment. If this imbalance is not silenced, it will continue and worsen. 
Therefore, it the need is immediately to bring thought patterns together to fight for more fair and balanced human relations and thus the opportunity to create understanding and co-operation that will ultimately led to violence against women in marriage ending soon.

The different view expressed by Irwan Abdullah that the discourse on the "weak woman" is so dominant in our daily lives that it had produced an intensive focus on the process of subordination of women, including feminists. That domination and subordination are important processes in the power relationship between men and women has been asserted continuously. But here, the tendency to place women as the subordinate has caused loss of perspective in explaining the reality of women's lives. Domination and subordination are construction processes active and ongoing, so it should not be the dominant or subordinate status that needs to be discussed, but the processes that lead to the need for domination. Why do men feel the need to be dominant?

In a hegemonic structure, a woman decides for her life: the option to take the unregistered marriage, even when she knows the risks to be faced, but it is the last option. Hegemonic structure did not come about easily, but through a process that has not only involved men and women, but was also tied to structural interests. In the establishment of hegemony, there has happened interaction, negotiation and decision-making which have then placed the woman in the structure of a particular relationship. In some cases, the decision to be 'istri siri' is actually the result of long 
negotiation. By the time we talk about the real dimensions of this kind we start talking from the perspective that we stand looking at the reality of women's lives. In this perspective, are we looking from the right perspective or should we look from several perspectives? The perspectives of women themselves are not being used to determine "what does the woman want", so that we do not know in depth the desires of women.

\section{Conclusion}

Nikah Siri, according to ecofeminism theory, continues to thrive because of this legal controversy - state versus religious law which allows for a duality at the heart of marriage law for Muslims in Indonesia. And the victims of this duality are women and children. The oppression that can be seen by the hierarchical, dualism and logical domination that are embedded in nikah siri leading women and children to be discriminated against. Concretely, the negative impact of nikah siri, particularly for the children, is evident in that a marriage certificate is a pre-requisite for being issued with a birth certificate, and a birth certificate is necessary for all manner of state procedures, including attendance at state schools.

When a woman agrees to marry without her marriage being registered, she gives up her own rights to protection from the state, and also the rights to maintenance and inheritance for any children that may result from the union. But the uncertainty of law of nikah siri force the women and children to bear the consequences by themselves. 


\section{BIBLIOGRAPHY}

Abdillah, Masykuri, Prof. Dr., dkk. 2005. Formalisasi Syariat Islam di Indonesia (Sebuah Pergulatan Yang Tak Pernah Tuntas). Jakarta: Renaisan. Cet. I.

Abdullah, Irwan (ed.). 2003. Sangkan Paran Gender. Cet II.

Yogyakarta: Pustaka Pelajar. 2001. Seks, Gender dan Reproduksi Kekuasaan.

Yogyakarta: Tarawang Press.

Arani, Amiruddin, dkk (Editor). 2002. Tubuh, Seksualitas dan

Kedaulatan Perempuan (Bunga Rampai Pemikiran Ulama Muda). Jakarta: Rahima (bekerjasama dengan LkiS dan The Ford Foundation). Cet.I.

Bainar, Dr. Hj. 1998. Wacana Perempuan dalam Ke Indonesiaan dan Kemodernan. Yogyakarta: PT Pustaka CIDESINDO bekerjasama dengan Universitas Islam Indonesia Yogyakarta dan Yayasan IPPSDM.

Chandraningrum, Dewi (editor). 2013. Ekofeminisme (Dalam Tafsir Agama, Pendidikan, Ekonomi dan Budaya). Yogyakarta: Jalasutra.

Ciciek, Farha. 1999. Ikbtiar Mengatasi Kekerasan Dalam Rumah

Tangga. Jakarta: Lembaga Kajian Agama dan Gender (bekerjasama dengan The Asia Foundation)

Departemen Agama. 2009. Al-Qur'an dan Terjemahnya Special for Women. Bandung: Sygma Examedia Arkanleema.

Departemen Pendidikan dan Kebudayaan. 1991. Kamus Besar Bahasa Indonesia. Edisi II, Cet. II; Jakarta: Balai Pustaka. 
Dzuhayatun, Siti Ruhaini dkk. 2002. Rekonstruksi Metodologis W acana Kesetaraan Gender Dalam Islam. Cet.I; Yogyakarta: Pustaka Pelajar bekerjasama dengan PSW IAIN (UIN) Sunan Kalijaga \& McGill-ICIHEP.

Fakih, Mansour, Dr. 2012. Analisis Gender dan Transformasi Sosial. Cet. XIV; Yogyakarta:Pustaka Pelajar.

Risalah Gusti. Cet. I.

Febriasih, Happy Budi dkk. 2008. Gender dan Demokrasi. Malang: Averroes Press

Halla $>$ q, Wael B. 2001. A History of Islamic Legal Theory diterjemahkan oleh E. Kusnadiningrat \& Abdul Haris bin Wahid dengan judul Sejarah Teori Hukum Islam. Cet.II. Jakarta: PT. RajaGrafindo Persada.

Hasyim, Syafiq. 2001. Hal-Hal yang Tak Terpikirkan tentang IsuIsu Keperempuanan Dalam Islam. Bandung: Mizan. Cet. I 2006. Understanding Women In Islam (An Indonesian Perspective). Jakarta: Solstice.

Ilyas, Hamim dkk (Editor). 2005. Perempuan Tertindas? Kajian Hadis-Hadis "Misoginis". Yogyakarta: eLSAQ Press (bekerjasama dengan Pusat Studi Wanita (PSW) UIN Sunan Kalijaga)

Marching, Soe Tjen. 2011. Kisah Di Balik Pintu (Identitas

Perempuan Indonesia: Antara Yang Publik \& Privat). Yogyakarta: Penerbit Ombak.

Muhammad, Hussein. 2004. Islam Agama Ramah Perempuan (Pembelaan Kiai Pesantren). Yogyakarta: LkiS (bekerjasama dengan Fahmina Institute). Cet.I. 
2001. Fiqh Perempuan (Refleksi Kiai atas

Wacana Agama dan Gender). Yogyakarta: LkiS (bekerjasama dengan The Ford Foundation dan FK3/Forum Kajian Kitab Kuning). Cet.I. dkk. 2001. Wajah Baru Relasi Suami-Istri

(Telaah Kitab 'Uqūd al-Lujjayn). Yogyakarta: LkiS (bekerjasama dengan The Ford Foundation). Cet.I.

Mulia, Musdah. Islam dan Hak Asasi Manusia (Konsep dan Implementasi). Yogyakarta: Naufan Pustaka. Cet. I. (ed.). 2001. Keadilan dan Kesetaraan Gender

(Perspektif Islam). Jakarta: Tim Pemberdayaan Perempuan Bidang Agama Depag RI.

Munir, Lily Zakiyah (ed.). 1999. Memposisikan Kodrat (Perempuan dan Perubahan dalam Perspektif Islam). Bandung: Mizan. Cet. I.

Munhanif, Ali. 2002. Mutiara Terpendam (Perempuan dalam

Literatur Islam Klasik). Jakarta: Gramedia Pustaka Utama.

Murniati, A. Nunuk P. 2004. Getar Gender (Buku Pertama). Magelang : Indonesiatera. Cet. I.

Magelang : Indonesiatera. Cet. I.

Nugroho, Riant, Dr. 2011. Gender dan Strategi Pengarusutamaannya di Indonesia. Cet. II. Yogyakarta : Pustaka Pelajar.

Nur Iman, Subono dkk (Editor). 1999. Catatan Perjalanan Suara Ibu Peduli. Jakarta: Yayasan Jurnal Perempuan. Cet. I. 
Nurkhoiron, Muhammad (Editor). 2010. Identitas Perempuan: Status, Pergeseran Relasi Gender dan Perjuangan Ekonomi Politik. Depok: Desantara Foundation. Cet. I.

Santosa, S. Edy (ed.). 2002. Islam dan Konstruksi Seksualitas. Yogyakarta: PSW IAIN Yogyakarta bekerjasama dengan The Ford Foundation dan Pustaka Pelajar. Cet. I.

Subhan, Zaitunah. 2002. Rekonstruksi Pemahaman Jender Dalam Islam (Agenda Sosio-Kultural dan Politik Peran Perempuan). Ciputat (Jakarta):el-Kahfi. Cet. I.

Sulaeman, Zulkarnaen \& Sofyan. 2011. Fikih Kontemporer: IsuIsu Gender Menghadirkan Teks Tandingan. Cet. I; Gorontalo:Sultan Amai Press.

Tim Pemberdayaan Perempuan Bidang Agama. 2001. Keadilan dan Kesetaraan Gender. Tim Pemberdayaan Perempuan Bidang Agama

Tong, Rosemarie. 2009. Feminist Thought (A More Comprehensive Introduction). Cet.III. Philadelphia: Westview Press.

Umar, Nasaruddin. 2010. Argumen Kesetaraan Gender. Cet. II; Jakarta : Dian Rakyat.

Wahid, Marzuki (Ed.). 2010. Kajian Islam Dalam Ragam Pendekatan. Cet. I; Purwokerto: STAIN bekerjasama dengan An Australian Government Initiative.

Walby, Sylvia. 1990. Theorizing Patriarchy. Oxford: Blackwell Publishers.

Warren, J. Karren. (Ed.).1996. Ecological Feminist Philosophies. Indiana Polis: Indiana University Press. 
----------------. 1997. Ecofeminism: Women, Culture and Nature. Indiana Polis: Indiana University Press.

\section{Jurnal :}

Yayasan Jurnal Perempuan. 1999. Suara Ibu Peduli. Jakarta: Divisi Penerbitan dan Kajian- Yayasan Jurnal Perempuan

Musawa, Vol 12 No. 1, 2013

\section{Website and Online Resources:}

Indonesia Lawyers? Club (ILC) Program, TV One http://www.metrotvnews.com http://www.mui.or.id http://www.hizbuttahrir.co.id http://www.puanamalhayati.or.id http://www.republika.co.id http://www.fshuinsgd.ac.id/2012/12/13 www.detikNews.com/ 12 Mei 2015 www.tribunnews.com 